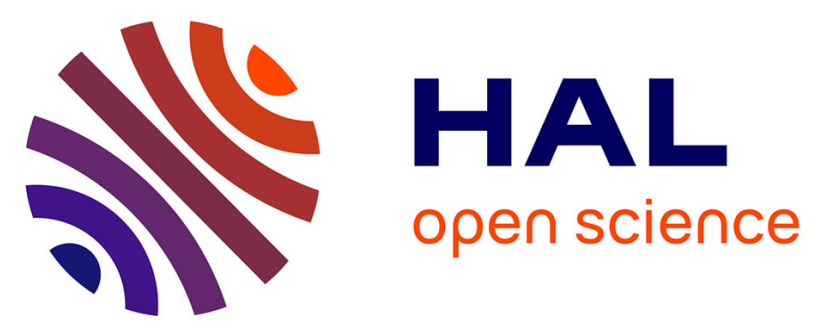

\title{
Multistatic Reluctance Network Modeling for the Design of Permanent Magnet Synchronous Machines
}

Hussein Dogan, Lauric Garbuio, Xuan Hoa Nguyen, Benoît Delinchant, Albert Foggia, Frédéric Wurtz

\section{- To cite this version:}

Hussein Dogan, Lauric Garbuio, Xuan Hoa Nguyen, Benoît Delinchant, Albert Foggia, et al.. Multistatic Reluctance Network Modeling for the Design of Permanent Magnet Synchronous Machines. CEFC'12 (IEEE Conference On Electromagnetic Field Computation), Nov 2012, Oita, Japan. hal00767045

\section{HAL Id: hal-00767045 \\ https://hal.science/hal-00767045}

Submitted on 21 Jan 2019

HAL is a multi-disciplinary open access archive for the deposit and dissemination of scientific research documents, whether they are published or not. The documents may come from teaching and research institutions in France or abroad, or from public or private research centers.
L'archive ouverte pluridisciplinaire HAL, est destinée au dépôt et à la diffusion de documents scientifiques de niveau recherche, publiés ou non, émanant des établissements d'enseignement et de recherche français ou étrangers, des laboratoires publics ou privés. 


\title{
Multistatic Reluctance Network Modeling for the Design of Permanent Magnet Synchronous Machines
}

\author{
Husseïn Dogan, Lauric Garbuio, Hoa Nguyen-Xuan, Benoît Delinchant, Albert Foggia and \\ Frédéric Wurtz \\ Grenoble Electrical Engineering Laboratory (G2Elab) ENSE ${ }^{3}$ (Grenoble INP-UJF, CNRS UMR 5529) BP 46 - \\ 38402 Saint Martin d'Hères Cedex, France \\ Hussein.dogan@g2elab.grenoble-inp.fr
}

\begin{abstract}
This paper deals with an original design methodology of Permanent Magnet Synchronous Machines (PMSM) using multistatic reluctance network modeling. Traditionally, models based on reluctance network use $d-q$ axis components in order to calculate the fundamental values of the torque and the back-emf. In this study, the reluctance network permits an angular rotation between rotor and stator to thereby extract the magnitude of the harmonics which are necessary for better optimization results. Besides, three different methods of calculation of the air-gap reluctances are presented and applied to the reluctance network. Then, simulation results are compared to Finite Element Analysis (FEA) in order to finally determine the best method. Ultimately, the proposed model shows precise and very fast results making it suitable for geometry optimization and to help designers obtaining a better sense of machines behavior.
\end{abstract}

Index Terms- permanent magnets synchronous machine; reluctance Network; harmonics; torque ripple; back-emf.

\section{INTRODUCTION}

Due to the use of permanent magnets in the rotor, PMSM have the highest power density and efficiency among all types of motors. Therefore, PMSM have found wide attention in designing machines for a lot of high performance industrial applications [1]. In the same time, specifications of such applications present severe constraints and the challenge of designers is to find the best machines giving the best performances.

In terms of optimization, modeling is a key point. Although analytical models are well known and offer a very fast computation time, they have the drawback to not be precise and to give only fundamental values of magnitudes [2]. Conversely, Finite Element Analysis (FEA) gives quite precise results but computation times could be very long. Then, FEA could not be used for the first steps of design.

The reluctance network modeling has the advantage of owning a good compromise between computation speed and accuracy. Besides, it provides the possibility to take into account the magnetic saturation and the slotting effects.

Traditionally, reluctance network models of PMSM are performed in $d-q$ axis using Park transformation for the calculation of the overall performance. The evaluation of the fundamental value of the torque and the back-emf are usually well estimated and sufficient for those machines design. However, for certain applications as in transportation and in Electric Vehicle (EV), specifications may have severe constraints on torque ripple and back-emf harmonics. Then, by taking into consideration those parameters during the optimization is very important in order to find the right optimal geometry. Sesanga [3] demonstrates the limitation of $d-q$ axis model on the optimization process for machines having constraints on the harmonic values. In this context, the reluctance network of the machine of this study is a multistatic model allowing the angular rotation of the rotor on an electrical period with a fixed step. Thus, not only fundamental values will be available but also harmonics values of the torque and the back-emf.

During the construction of the reluctance network, the most difficult point concerns the modeling of the air-gap reluctances linking the rotor and the stator. The calculation of these reluctances can be performed in several ways. This paper presents three different methods which are:

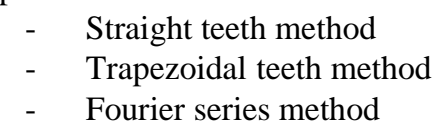

Each method is modeled, simulated and compared to FEA in order to determine the most appropriate one for machines design. As an illustration, the reluctance network models a three-phase interior PMSM dedicated to the traction of an EV. Likewise, the software used for the modeling has the great advantage to provide the value of the gradient of the output parameters. Thus, optimization with deterministic algorithm can be used in order to fastly converge to the optimal solution.

Ultimately, section II introduces the PMSM and the associated reluctance network that has to be constructed. Section III presents the three methods and the simulation results compared to FEA. Finally, conclusion of this paper and prospects of future works are given in section IV.

\section{REluCtAnCE Network OF THE PMSM}

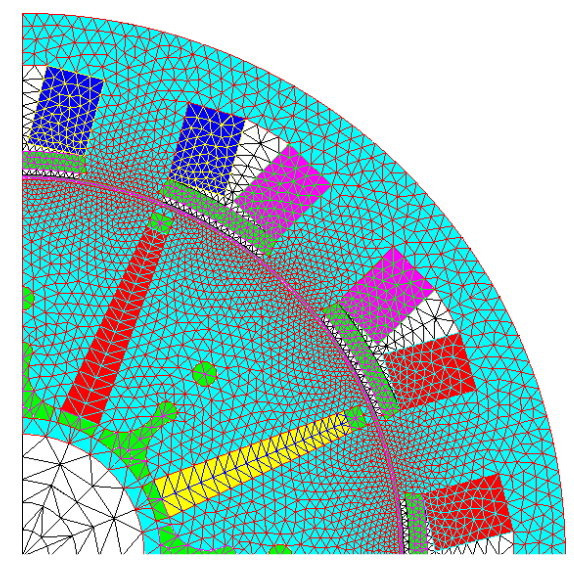

Fig.1 Mesh of the 12/8 PMSM 
In order to validate the results obtained by the multistatic reluctance network, the PMSM has been modeled with Finite Element Method (FEM) in the software Flux2D. Due to the periodicity of the 12 slots / 8 poles machine, only one quarter has to be modeled. An overview of the mesh is also given in fig. 1 .

\section{A. Characteristics of the PMSM}

Main characteristics of the PMSM are given in table I:

TABLE I: Main features of the PMSM

\begin{tabular}{|c|c|}
\hline Number of stator slots & 12 \\
\hline Number of rotor poles & 8 \\
\hline Max. Power & $58 \mathrm{~kW}$ \\
\hline Max. Torque @ 1,500 rpm & $215 \mathrm{~N} . \mathrm{m}$ \\
\hline Max. current (RMS) & $63.6 \mathrm{~A}$ \\
\hline Number of turns (coils) & 50 \\
\hline Diameter & $200 \mathrm{~mm}$ \\
\hline Depth & $200 \mathrm{~mm}$ \\
\hline Air-gap & $0.9 \mathrm{~mm}$ \\
\hline
\end{tabular}

\section{B. Construction of the reluctance network}

For the construction of the reluctance network, the first step is to observe the paths of the magnetic flux with a finite element analysis of the machine. Then, fundamental elements as reluctances, magneto-motive forces (MMF) and magnets can be placed according to these magnetic flux paths. Firstly, the basic patterns of the stator and the rotor have to be determined and after that, air gap reluctances could be placed. Fig. 2 shows the main elements of the network for $12 / 8$ machine:

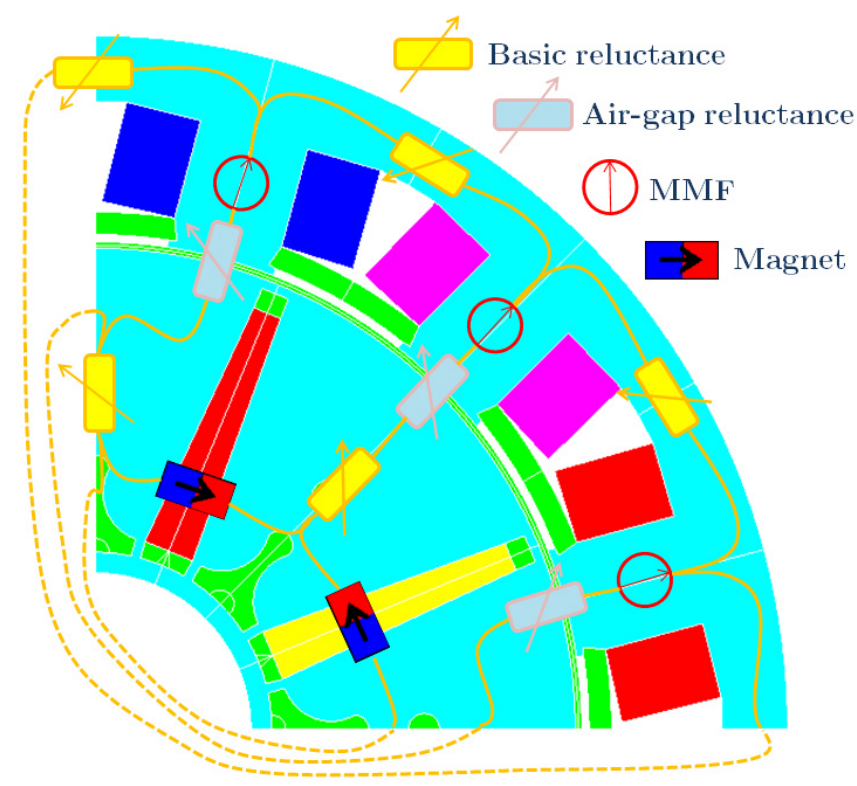

Fig. 2 Construction of the reluctance network: 12/8 PMSM

For the multistatic model, the air gap reluctances have to take into account the rotational movement of the rotor and each pole has to be connected to each tooth via a reluctance. Finally, the reluctance network of the 12/8 machine is modeled in the software RelucTOOL and is represented in fig. 3.

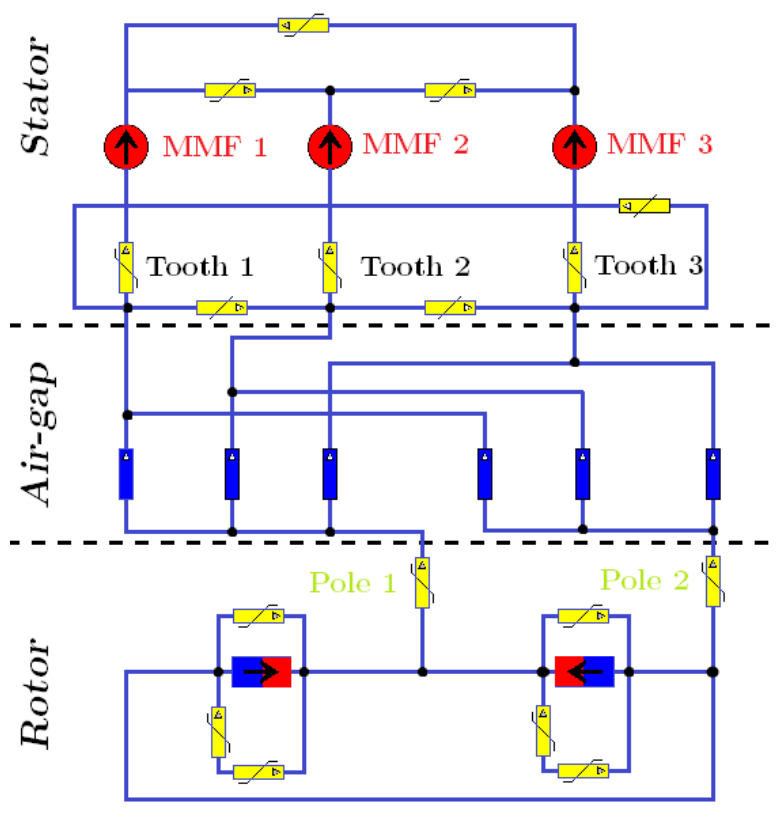

Fig.3 Reluctance network of the 12/8 PMSM

Magneto-motive forces are expressed as $N_{s} . I$ where $N_{s}$ is the number of turns of the coils and $I$ is the current. Also, the parameters that characterize the magnets are the length, the surface and the remanent induction. For the reluctances, the general expression is:

$$
\mathfrak{R}=\frac{1}{\mu_{0} \cdot \mu_{r}} \cdot \frac{L}{S}
$$

with $\mu_{r}$ the relative permeability; $L$ the length and $S$ the surface of the reluctance. For air-gap reluctances, the expression becomes:

$$
\mathfrak{R}_{\text {air-gap }}=\frac{1}{\mu_{0}} \cdot \frac{\text { air }- \text { gap }}{\text { depth } \cdot \text { width }}
$$

The depth and the air-gap values are the same for all air-gap reluctances of the circuit. Then, the only one parameter that has to be determined is the width for each reluctance. Besides, during the rotation of the rotor all parameters are fixed except the widths of the air-gap reluctances which have to be calculated for each angular pitch.

\section{Calculation of Air-gap Reluctances}

The widths of the air-gap reluctances can be calculated in several ways. Here, we investigate three different methods which are:

- $\quad$ Straight teeth method

- Trapezoidal teeth method

- Fourier series method

\section{A. Straight teeth method}

The width of the air-gap reluctance corresponds to the common part between the teeth of the stator and the pole of the rotor. Its value can be calculated as:

$$
\text { Width }=R \cdot \theta_{r-s}
$$


where $R$ is the radius of the rotor and $\theta$ is the common angle between the teeth and the pole. For this method, the value of $\theta$ is geometrically determined and is equal to (see fig. 4):

$$
\theta_{r-s}=\left\{\begin{array}{c}
A \rightarrow \theta_{r 2}-\theta_{s 1} \\
B \rightarrow \theta_{s 2}-\theta_{s 1} \\
C \rightarrow \theta_{s 2}-\theta_{r 1} \\
D \rightarrow 0
\end{array}\right.
$$

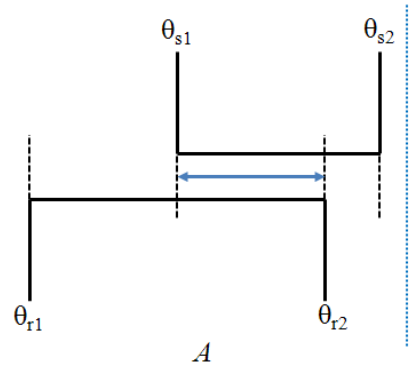

A

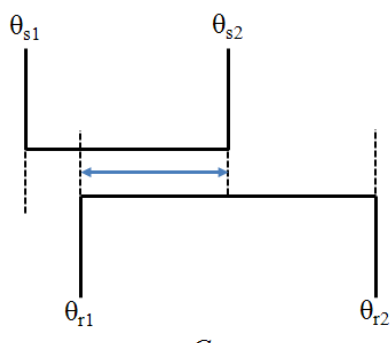

$C$

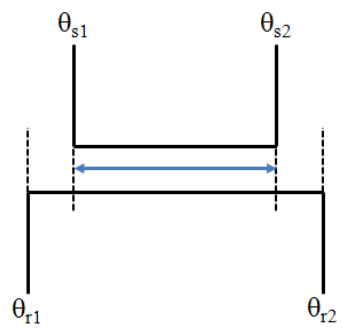

$B$

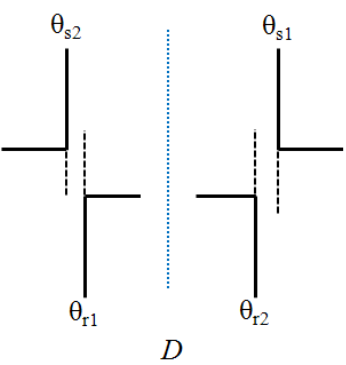

Fig.4: Determination of the width of air-gap reluctances

After the implementation of the method in RelucTOOL, simulations can be performed in order to calculate the value of the torque and the back-emf.

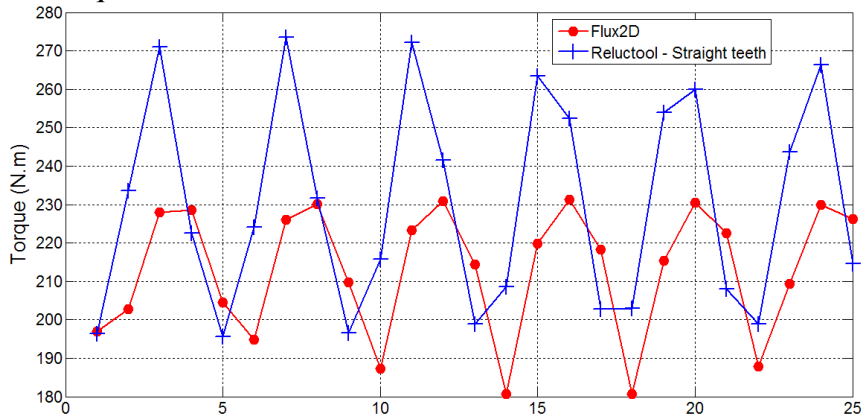

Fig.5 Torque of the machine - Straith teeth method

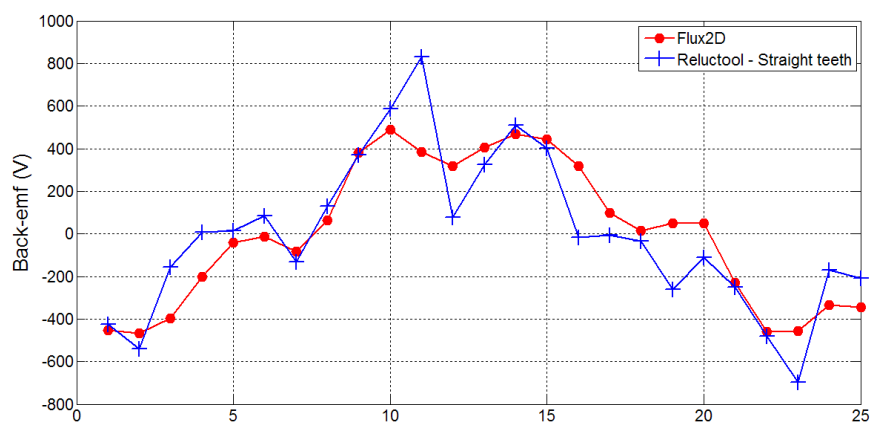

Fig.6 Back-emf of the machine - Straith teeth method
TABLE II: Simulation Results - Straight teeth method

\begin{tabular}{|c|c|c|}
\cline { 2 - 3 } \multicolumn{1}{c|}{} & Flux2D & Straight teeth method \\
\hline Mean torque & 212.9 & 230 \\
\hline Ripple torque $-\mathrm{H}_{6}$ & 20.9 & 19.1 \\
\hline Ripple torque $-\mathrm{H}_{12}$ & 4.9 & 2.2 \\
\hline Back-emf $-\mathrm{H}_{1}$ & 445.8 & 431.3 \\
\hline Back-emf $-\mathrm{H}_{3}$ & 8.4 & 42.4 \\
\hline Back-emf $-\mathrm{H}_{5}$ & 128.7 & 176 \\
\hline Back-emf $-\mathrm{H}_{7}$ & 37.7 & 127.8 \\
\hline Computation time & $250 \mathrm{sec}$. & $180 \mathrm{~ms}$ \\
\hline
\end{tabular}

As it can be observed (see fig. 5, fig. 6 and table II), the value of the mean torque, the $6^{\text {th }}$ harmonic of the torque ripple and the fundamental of the back-emf show good accordance with FE results. Besides, the computation time of the simulation with RelucTOOL is very fast compared to FEA. However, the values of the back-emf harmonics, i.e. $3^{\text {rd }}, 5^{\text {th }}$ and $7^{\text {th }}$ are overestimated. The differences may result from the method which doesn't take into account some flux path through the air-gap. Indeed, in the case if $\theta_{r 2}$ is smaller than $\theta_{s 1}$ and also has a close value to $\theta_{s 1}$ (instances $D$ of fig. 4), this method gives a value of the width equal to 0 . Actually, leakage fluxes exist and have to be considered. This can be realized with other methods as the following ones.

\section{B. Trapezoidal teeth method}

In order to consider the leakage fluxes, the teeth and the poles of the machine will not be modeled as square shape but will have a gradient at the ends. Fig.7 shows the waveform of the teeth and the poles:

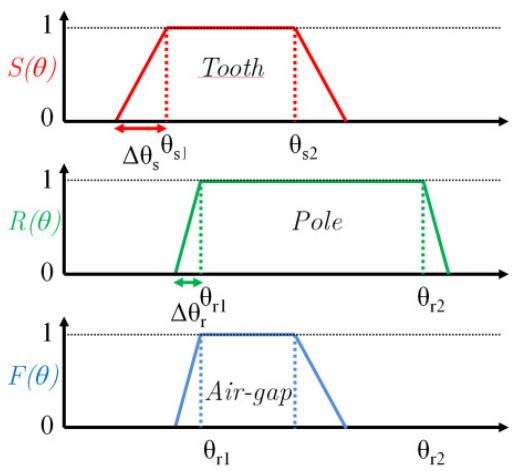

Fig.7 Width of the air-gap reluctances - Trapezoidal method

Then, width of the air-gap reluctances is calculated as below:

$$
\begin{gathered}
\text { Width }=R \cdot \theta_{r-s}=R \cdot \int F(\theta) \cdot d \theta \\
\text { where } F(\theta)=S(\theta) \cdot R(\theta)
\end{gathered}
$$

Furthermore, the gradients $\left(\Delta \theta_{\mathrm{s}}\right.$ and $\left.\Delta \theta_{\mathrm{r}}\right)$ of the stator and rotor functions have to be determined from FEA by the observation of the leakage fluxes at the ends of the teeth and the poles. For this application, $\Delta \theta_{\mathrm{s}}$ is equal to 6 mechanical degree angle and $\Delta \theta_{\mathrm{r}}$ is equal to 3 degree.

Results of this method are given in fig. 7-8 and in table III. Overall, the values are better than first method. Estimation of the mean torque and back-emf harmonics shows as well, more precise values. However, the fundamental of the back-emf is too low compared to FEA. The difference may originate from the discontinuities that are always present. 


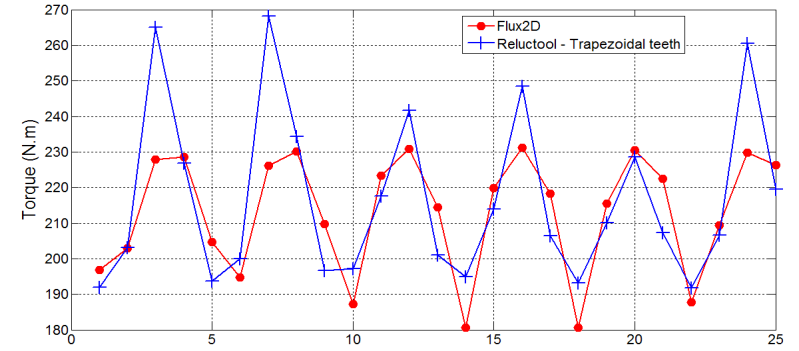

Fig.8 Torque of the machine - Trapezoidal teeth method

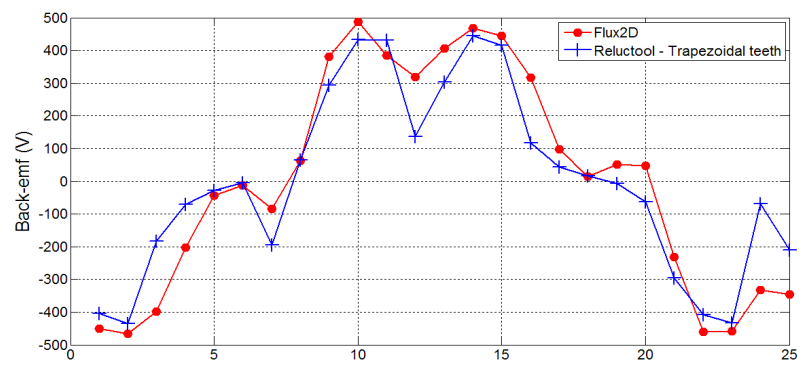

Fig.9 Back-emf of the machine - Trapezoidal teeth method

TABLE III: Simulation Results - Trapezoidal teeth method

\begin{tabular}{|c|c|c|}
\cline { 2 - 3 } \multicolumn{1}{c|}{} & Flux2D & Trapezoidal teeth method \\
\hline Mean torque & 212.9 & 216.7 \\
\hline Ripple torque $-\mathrm{H}_{6}$ & 20.9 & 14.9 \\
\hline Ripple torque $-\mathrm{H}_{12}$ & 4.9 & 3.7 \\
\hline Back-emf $-\mathrm{H}_{1}$ & 445.8 & 344 \\
\hline Back-emf $-\mathrm{H}_{3}$ & 8.4 & 12.5 \\
\hline Back-emf $-\mathrm{H}_{5}$ & 128.7 & 152 \\
\hline Back-emf $-\mathrm{H}_{7}$ & 37.7 & 45.2 \\
\hline Computation time & $250 \mathrm{sec}$. & $540 \mathrm{~ms}$ \\
\hline
\end{tabular}

\section{Fourier series method}

This last method is based on the same principle of the trapezoidal method. The only difference concerns the functions $S(\theta)$ and $R(\theta)$ which are drawn from Fourier series. The term order, here equal to 6 , is chosen appropriately in order to reproduce the effects of leakage fluxes.

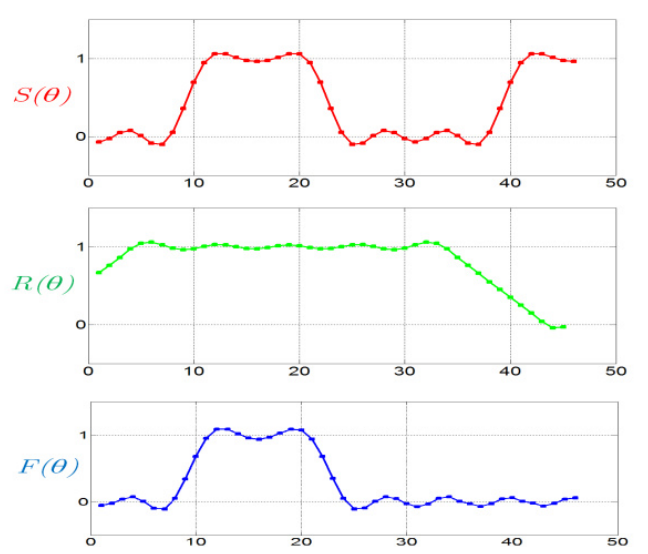

Fig.10 Width of the air-gap reluctances - Fourier series method

Considering fig. 10-11 and table IV, very good accordance of the results obtained with FEA can be observed. Values of the mean torque and the back-emf are very close to FEA. Solely the torque ripple is underestimated. Thus, this method can be used for optimization processes which require fast and precise models.

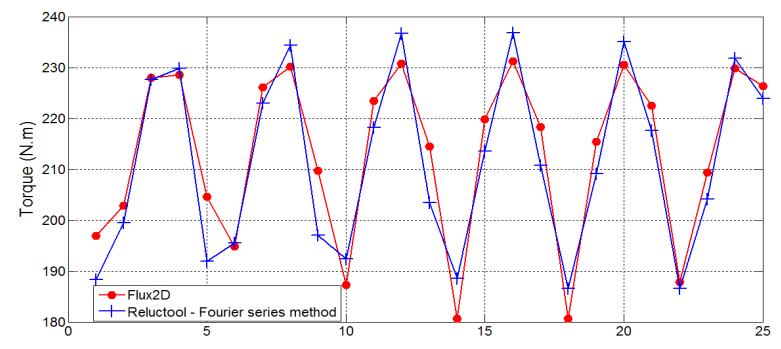

Fig.11 Torque of the machine - Fourier series method

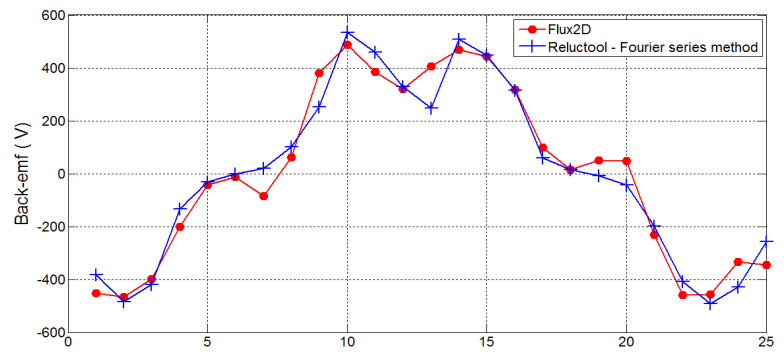

Fig.12 Back-emf of the machine - Fourier series method

TABLE IV: Simulation Results - Fourier series method

\begin{tabular}{|c|c|c|}
\cline { 2 - 3 } \multicolumn{1}{c|}{} & Flux2D & Fourier series method \\
\hline Mean torque & 212.9 & 211.3 \\
\hline Ripple torque $-\mathrm{H}_{6}$ & 20.9 & 12.2 \\
\hline Ripple torque $-\mathrm{H}_{12}$ & 4.9 & 1.3 \\
\hline Back-emf $-\mathrm{H}_{1}$ & 445.8 & 432.7 \\
\hline Back-emf $-\mathrm{H}_{3}$ & 8.4 & 4.6 \\
\hline Back-emf $-\mathrm{H}_{5}$ & 128.7 & 128.2 \\
\hline Back-emf $-\mathrm{H}_{7}$ & 37.7 & 36.9 \\
\hline Computation time & 250 sec. & $340 \mathrm{~ms}$ \\
\hline
\end{tabular}

\section{CONCLUSION}

In this paper, multistatic reluctance networks have been considered in order to extract fundamental and also harmonics values of torque and back-emf. For this, three different methods permitting the calculation of the air-gap reluctances have been investigated. Last method exhibited very good concordance with FE results. Thus, optimization process and sensibility analysis can be performed with gradient methods in the case that the derivative of the model is given. With the software RelucTOOL, the derivation of the reluctance network is automatically generated and very fast optimization can be realized.

\section{REFERENCES}

[1] M. Barcaro and al., Performance Evaluation of an Integrated Starter Alternator using an Interior Permanent Magnet Machine, IET Electr. Power Appli., vol. 4, Iss. 1, pp. 539-546, 2010

[2] T. Raminosoa and al., Reluctance Network Modelling of Surface Permanent Magnet Motor Considering Iron Linearities, Int. Journ. on Energy Conversion and Management, vol. 50, pp. 1356-1361, 2009

[3] B. du Peloux and al., Automatic Generation of Sizing Static Models Based on Reluctance Networks for the Optimization of Electromagnetic Devices. IEEE Trans. on Magnetics, Vol. 42, Iss. 4, pp. 715-718, 2006

[4] Bill Sesanga, Optimization of ranges: application for the conception of radial permanent magnet synchronous motors. $\mathrm{PhD}$ thesis, Grenoble Institute of Technology, (Grenoble-INP), 2011 (French) 